\title{
Resistensi Ulama Terhadap Konsep Takharuj Dalam Fikih Hanafiyah
}

\author{
Elfia \\ Universitas Islam Negeri Imam Bonjol Padang \\ elfiauinib@gmail.com
}

\begin{abstract}
This research is based on the desire to know the cause of rejection (resistance) of ulama to the concept of takharuj which isdeveloped in fikih Hanafiyah. The Hanafiyah scholar follows the way of takharuj (the removal of one or more beneficiaries from the heirs of the beneficiary in return for the benefit of other beneficiaries either by using his own property or from the heritage property. However,there is a weak point in the completion of the law so that scholars outside Hanafiyah refuse and do not practice it. This research is a library research by collecting and reading jurisprudence literature that contains the opinion of the major ulama and Hanafiyah scholars as the primary material. The approach used in this study is a normative approach. There is a resistance (rejection) of scholars to the concept of takharij submitted by Hanafiyah scholars because takharuj is considered as a legacy sale but the object of trading is not yet or is not clear. This is contrary to the general principle of muamalah maaliyah. Besides, giving inheritance to the heirs before the person died, even though the purpose was to benefit the heirs, violates and conflicts with the prophecy of qath'i, and the principle of ijbari in inheritance.
\end{abstract}

Keywords: Takharuj, Hanafiyah, Resistance

\begin{abstract}
Abstrak
Penelitian ini bertujuan untuk mengetahui penyebab adanya penolakan (resistensi) ulama terhadap konsep takharuj yang berkembang dalam fikiih Hanafiyah. Ulama Hanafiyah menempuh cara takharuj (keluarnya seorang atau lebih ahli waris dari kelompok ahli waris dengan imbalan yang diberikan ahli waris lain baik dengan menggunakan hartanya sendiri atau dari harta warisan. Namun terdapat titik lemah dalam penyelesaian takharuj sehingga ulama di luar Hanafiyah menolak dan tidak mengamalkannya. Penelitian ini adalah penelitian kepustakaan dengan mengumpulkan dan membaca literatur fikih yang memuat pendapat jumhur ulama dan ulama Hanafiyah sebagai bahan primer. Pendekatan yang digunakan dalam penelitian ini adalah pendekatan normatif. Adanya resistensi (penolakan)
\end{abstract}

Al Istinbath : Jurnal Hukum Islam vol. 3, no. 1, 2018

STAIN Curup-Bengkulu | p-issn: 2548-3374; e-issn: 2548-3382

Available online at : http://journal.staincurup.ac.id/index.php/alistinbath 
jumhur ulama terhadap konsep takharuj yang dikemukakan oleh ulama Hanafiyah disebabkan takharuj dianggap sebagai jual beli warisan namun objek yang diperjualbelikan belum ada atau belum jelas. Hal ini berbenturan dengan prinsip umum dalam muamalah maaliyah. Di samping itu, dengan diberikan warisan kepada ahli waris sebelum pewaris meninggal, walaupun tujuan dilakukannya untuk kemashlahatan ahli waris, namun dalam mencapai tujuan tersebut menyalahi dan berbenturan dengan dalil qath'i, dan prinsip ijbari dalam kewarisan.

Kata Kunci: Takharuj, Hanafiyah, Resistensi

\section{Pendahuluan}

Asas ijbari dalam hukum kewarisan Islam mengandung arti bahwa peralihan harta dari seseorang yang telah meninggal kepada ahli warisnya berlaku dengan sendirinya menurut kehendak Allah tanpa tergantung kepada kehendak dari pewaris atau permintaan dari ahli warisnya. Unsur paksaan sesuai dengan arti terminologis tersebut terlihat dari segi bahwa ahli waris terpaksa menerima kenyataan perpindahan harta kepada dirinya sesuai dengan yang telah ditentukan.

Prinsip ijbari ini tercermin dari ketentuan Hukum Kewarisan Islam ${ }^{1}$ itu sendiri ketika dilihat ketentuan mengenai aturan warisan tersebut secara rinci telah dijelaskan Allah SWT dalam beberapa ayat al-Qur'an dan sunnah Nabi, di antaranya surat an-Nisa' ayat 7 sampai ayat $14 .^{2}$ Dalam ayat tersebut tersirat bahwa kewajiban bagi setiap muslim untuk menyelesaikan pembagian harta warisan berdasarkan hukum yang telah ditetapkan Allah SWT tersebut, tanpa dibolehkan untuk merubahnya, karena ada hukuman dan ancaman yang akan diberikan oleh Allah SWT terhadap muslim yang tidak menjalankan hukum itu.

Berdasarkan ayat tersebut, seorang muslim yang melanggar ketentuan hukum yang telah dibuat oleh Allah SWT, digolongkan sebagai muslim yang durhaka kepada Allah SWT dan Rasul-Nya. Hukum kewarisan merupakan hukum yang bersifat imperatif (memaksa). ${ }^{3}$ Artinya, hukum yang dalam keadaan

1 Hukum Kewarisan Islam merupakan seperangkat peraturan tertulis berdasarkan wahyu Allah dan sunnah Nabi tentang hal ihwal peralihan harta atau berujud harta dari orang yang telah meninggal kepada yang masih hidup, yang diakui dan diyakini berlaku dan mengikat untuk semua yang beragama Islam. Amir Syarifuddin, Hukum Kewarisan Islam,(Jakarta: Prenada Media, 2004), h. 5

2 Lihat QS. Surat an-Nisa' ayat 7,8,9,10,11,12,13, dan 14

${ }_{3}$ Menurut Achmad Sanusi, sebagaimana dikutip oleh Soedjono Dirdjosisworo, dari sudut lain mengenai hal kerjanya, hukum itu dapat dibedakan dalam hukum memaksa dan hukum mengatur. Hukum memaksa diartikan dengan hukum yang dalam keadaan apapun dapat dilaksanakan, oleh para pencari hukum dan para fungsionaris. Ia tidak memperkenankan penyimpangan. Lihat Soedjono Dirdjosisworo, Penganatar Ilmu Hukum, Jakarta: CV.Rajawali, 
kongkrit harus ditaati atau hukum yang tidak boleh ditinggalkan oleh para pihak dan harus diikuti. Ketentuan-ketentuan yang bersifat memaksa itu berlaku bagi para pihak yang bersangkutan maupun hakim sehingga hukum itu sendiri harus diterapkan meskipun para pihak mengatur sendiri hubungan mereka. ${ }^{4}$ Apabila terjadi penyimpangan berarti akan timbul akibat secara yuridis, perbuatan tersebut menjadi batal atau tidak sah atau batal menurut hukum (di bidang hukum perdata). Adapun di bidang hukum pidana membawa akibat lain yang berbeda dengan hukum perdata. ${ }^{5}$

Apabila dikatakan hukum kewarisan adalah hukum yang bersifat regulatif (fakultatif) artinya, hukum yang bersifat mengatur atau hukum pelangkap, dalam keadaan kongkrit, hukum tersebut dapat dikesampingkan oleh perjanjian yang diadakan oleh para pihak dan secara apiori tidaklah mengikat atau wajib ditaati. ${ }^{6}$ Allah SWT tidak akan memberikan ancaman bagi siapapun yang tidak melaksanakan hukum tersebut dan ketentuan bagian ahli waris seperti yang diatur dalam surat an-Nisa' ayat 11 dan 12 tidaklah mengikat dan wajib ditaati. Dalam pembagian harta warisanpun dapat diserahkan kepada ahli waris.

Apabila dilihat dalam prakteknya, para ulama dan mujtahid tidak sepenuhnya tunduk pada aturan-aturan yang telah ditetapkan tersebut. Mereka dalam menyelesaikan beberapa kasus dalam pembagian harta warisan, keluar dari aturan yang ada. Hal ini pada dasarnya bertitik tolak dari adanya pemikiran

1984), cet.Ke-1, h.165. Lihat juga rumusan lain yang dijelaskan oleh Kansil yakni hukum yang memaksa, yaitu hukum yang dalam keadaan bagaimanapun juga harus dan mempunyai paksaan mutlak. C.S.T Kansil, Pengantar Ilmu Hukum dan Pengantar Tata Hukum Indnesia, Jakarta: Balai Pustaka, 1976), h.74-75

${ }^{4}$ C.S.T Kansil, loc.cit

${ }^{5} \mathrm{Hal}$ ini dicontohkan oleh salah seorang ahli ilmu hukum, Mahmud Marzuki, tentang ketentuan pasal 913 Burgerlijk Wetboek Indonesia, bahwa "Legitieme portie atau bagian warisan menurut Undang-undang ialah suatu bagian dari harta benda yang harus diberikan kepada ahli waris dalam garis lurus menurut Undang-undang, yang terhadapnya orang yang meninggal dunia tidak boleh menetapkan sesuatu, baik sebagai hibah antara orang-orang yang masih hidup maupun sebagai wasiat". ${ }^{5}$ Berdasarkan ketentuan tersebut, pewaris dengan testamen sekalipun tidak dibolehkan untuk mengurangi bagian terkecil dari ahli waris sekecil apapun. Soedjono Dirdjosisworo, loc.cit

${ }^{6}$ Menurut Soejono Dirdjosisworo hukum mengatur itu tidak memaksa. Akan tetapi memaksanya hukum mengatur itu tergantung dari syarat-syarat terentu. Apabila syarat-syarat itu dipenuhi, maka memaksalah hukum mengatur itu seperti hukum memaksa sendiri, baik kepada fungsionaris hukum atau kepada pencari-pencari hukum yang berkepentingan. Syarat-syarat yang dimaksud:1).Yang berkepentingan oleh karena hukum mengatur itu membolehkan penyimpangan-penyimpangan tidak menggunakan kelonggaran yang ada, tetapi ia justru menyatakan menerima untuk tunduk pada hukum itu. 2).Yang berkepentingan tidak usah menyatakan takluk pada hukum mengatur itu, akan tetapi tidak menetapkan ketentuanketentuannya sendiri. Kekosongan-kekosongan ini memberikan tempat untuk berlakunya dan memeksanya hukum mengatur. Lihat Soedjono Dirdjosisworo, loc.cit 
tentang kemashlahatan yang akan dihasilkan dari pembagian harta warisan tersebut. Adakalanya seseorang yang mempunyai bagian yang besar, adalah orang yang kaya yang tidak membutuhkan. Sedangkan di sisi lain seseorang dengan bagian yang kecil merupakan orang miskin yang membutuhkan. Secara hukum, seorang ahli waris tidak mempunyai kewajiban apa-apa untuk membantu ahli waris yang lain. Sehingga jika dilakukan pembagian secara normati formal, dalam hal ini tidak memberikan mashlahat kepada mereka. Dengan pertimbangan seperti itu, dilakukan pengurangan dan penambahan terhadap beberapa ketentuan yang telah ada di dalam hukum kewarisan yang membuat beberapa aspek normatif dalam sistem kewarisan Islam dikesampingkan.

Dalam mazhab Hanafiyah berkembang bentuk penyelesaian kewarisan yang diistilahkan dengan Takharuj. Penyesuaian secara takharuj ini adalah sebentuk tindakan kebijaksanaan yang hanya digunakan dalam keadaan tertentu bila kemashlahatan dan keadilan memerlukannya. Hal ini ditempuh semata dengan maksud meniadakan kesempitan dalam muamalat tanpa sama sekali menghindarkan diri dari ketentuan yang ditetapkan oleh Allah SWT. Dengan cara ini suatu kesulitan dalam memecahkan persoalan pembagian warisan dalam keadaan tertentu dapat diselesaikan. Akan tetapi persoalan ini mendapatkan perhatian khusus oleh para ulama karena penyelesaian secra takharuj dianggap menyalahi beberapa prinsip dalam hukum kewarisan Islam.

Jika dicermati, takharuj secara zahir merupakan salah satu bentuk dalam penyelesaian kewarisan yang keluar dari aturan. Ada beberapa bentuk penyelesaian kewarisan yang lain yang pernah dilakukan oleh ulama atau sahabat pada masanya seperti penyelesaian 'aul dan radd, gharawain dan musyarakah. Namun penyelesaian ini tidak dianggap suatu yang menyalahi nash karena mayoritas ulama memakainya. Namun dalam persoalan takharuj, hanya ulama di kalangan Hanafiyah yang memandang sebagai suatu solusi atau hillah syar'i dalam menjalankan hukum waris. Berdasarkan kepada bentuk dan cara penyelesaian secara takharuj, penelitian ini berupaya untuk menjawab persoalan: bagaimana sesungguhnya konsep takharuj menurut ulama Hanafiyah dan kenapa mayoritas ulama (selain Hanafiyah) menolak takharuj yang dikembangkan oleh ulama Hanafiyah sebagai salah satu bentuk penyelesaian kewarisan.

Dalam upaya memperoleh data dan rumusan yang jelas dalam menjawab semua permasalahan dalam penelitian ini, maka pendekatan yang digunakan adalah penelitian kepustakaan (library research) atau normatif. ${ }^{7}$ Pada penelitian kepustakaan atau penelitian normatif maka data yang digunakan adalah data

${ }^{7}$ Soerjono Soekanto dan Sri Mamudii, Penelitian Hukum Normatif : Suatu Tinjauan Singkat, (Jakarta: PT. Rajagrafindo Persada, 1983), h. 13-14 
skunder. ${ }^{8}$ Data skunder terdiri dari bahan primer dan bahan skunder. Bahan primer dalam penelitian ini diambil dari karya ulama Hanafiyah sendiri.

Sejauh ini penelitian yang membahas tentang hukum kewarisan Islam sudah dilakukan oleh peneliti-peneliti lain, namun objek penelitian yang telah ada bukan mengenai objek yang penulis teliti. Di antaranya: Pertama, Umar Syihab, Hukum Kewarisan Islam dan Pelaksanaannya di Wajo, disertasi pada Program Pascasarjana IAIN Sultan Alaudin Makasar 1996. Penelitian ini menggunakan pendekatan teologis, sosiologis dan normative. Penelitian ini menyimpulkan bahwa penerimaan syara'oleh sistim Hukum Adat Bugis Wajo "Pangadereng" telah melahirkan pelaksanaan hukum Kewarisan Islam di Wajo.

Kedua, Ali Yasa Abu Bakar, Ahli Waris Sepertalian Darah: Kajian Perbandingan Terhadap penelaran Hazairin dan Penalaran Fikih Mazhab, diertasi pada Program Pascarajana IAIN Syarif Hidayatullah Jakarta, 1996. Penulisan ini berkesimpulan bahwa ijtihad Hazairin telah menciptakan sebuah sistim yang lebih padu dan menyeluruh, yakni melalui pendekatan antropologi telah membuka peluang menafsirkan yata-ayat kewarisan dalam kerangka yang lebih luas.

Adanya penelitian tentang tema ini bertujuan untuk mengungkap secara jelas bagaimana konsep takharuj yang dikembangkan oleh ulama Hanafiyah, dan apa dasar bagi ulama Hanafiyah membolehkan praktek takharuj ini dalam pembagian warisan. Di samping itu, juga untuk mengetahui titik lemah dan sisi mana dari prinsip hukum kewarisan Islam yang dilanggar sehingga muncul penolakan dari mayoritas ulama terhadap konsep takharuj ini.

\section{Pembahasan}

\section{Pengertian Takharuj}

Kata takharuj merupakan kata yang berasal dari kharaja yang berarti keluar. Ketika kata ini diwazankan dengan wazan tafa'ul (shigat musyarakah)

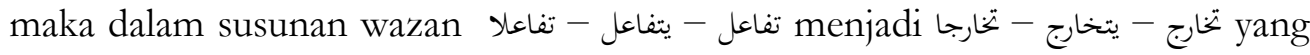
memiliki arti saling keluar atau saling mengundurkan diri yang terjadi antara dua pihak. Dalam salah satu kamus, takharuj secara etimologi diartikan dengan تفاعل من الخروج (saling berbuat untuk keluar) sehingga dalam kalimat تخارج القوم berarti masing-masing saling berbuat untuk keluar dari memberikan nafkah atas seukuran nafkah yang diberikan temannya. Adapun dalam kalimat تخارج الشركاء berarti masing-masing keluar atau mengundurkan diri dari perserikatan yang

8 Ibid., h. 24 
dilakukannya terhadap kepemilikan dengan cara jual beli. Sedangkan kalimat تخارج الورثة berarti sebagian mereka mengundurkan diri (keluar) dari menerima bagian harta warisan dengan cara jual beli, ishlah dan sejenisnya. ${ }^{9}$

Dalam pengertian secara bahasa ini dapat dipahami bahwa jika yang mengundurkan diri itu hanya dilakukan oleh seseorang saja tanpa ada pihak lain yang ikut menyepakati di dalamya atau tidak ada keikutsertaan pihak lain menyetujui pengunduran diri tersebut maka tidak dinamakan dengan takharuj. Ada sejumlah istilah yang berkaitan dengan makna takharuj jika dikaitkan dengan makna secara bahasa. Kadang-kadang salah satu istilah ini digunakan untuk mana takharuj oleh ulama faraidh. Di antara istilah itu al-qismah, al-sulbu, dan albai. Perbedaan istilah ini dengan takharuj adalah:

1. Al-Qismah (al-taqasum). Secara lughah al-qismah berarti bagian, batasan. Secara istilah al-qismah berarti sesuatu yang membedakan sebagian hak dan bagian dari sebagian yang lain. Takharuj dalam sebagian bentuknya dipandang sebagai bagian di antara ahli waris. Paling tidak ada dua hal yang menjadi pembeda di antara kedua bentuk istilah ini:

- Harta yang dibagi dalam bentuk qismah, merupakan satu bagian dari harta yang diserikatkan. Adapun dalam takharuj, orang yang keluar mengambil bagian tertentu baik dari harta peninggalan atau dari selainnya, bukan dalam bentuk harta yang diserikatkan. ${ }^{10}$

- Pada dasarnya dalam qismah, tiap orang yang berserikat mengambil bagiannya sesuai dengan hak yang mesti ia terima menurut syara'. Adapun dalam takharuj terkadang orang yang mengundurkan diri dari menerima warisan itu mengambil bagian lebih banyak atau sedikit dari hak yang mesti ia terima sesuai dengan kemashlahatannya atau kemashlahatan ahli waris.

2. As-Shulh (At-Tashalub)

Takharuj dalam beberapa bentuknya dipandang juga sebagai ishlah di antara ahli waris, namun ada tiga hal yang membedakannya dengan ishlab:

${ }^{9}$ Ibn Manzhur al-Ifriqiy, Lisan al-Arab, (Beirut: Dar al-Ihya' al-Turast al-Islamiy,1419 H), cet ke-3, Jilid .4, h. 53-54

10 Nashir bin Muhammad bin Masyriy al-Ghamidiy, al-Takharuj Baina al-Waratsah Abkamuhu wa Shunarubu fi al-Fiqh al-Islamiy, (Makkah al-Mukarramah: Jami’ah Ummu al-Qura,tt), h. 195-196. Lihat juga Mausu'ah Fiqhiyyah Al-Kuwaitiyah, (Kuwait: Zaratul Auqaf wa as-Syu'un alIslamiyah, 1408), cet ke-2, Jil.11, h. 5 
a. Ishlah itu umum untuk seluruh harta dan selainnya, sementara takharuj terbatas ishlah dalam bentuk harta saja. ${ }^{11}$

b. Ishlah dengan makna umum biasanya terjadi setelah adanya perselisihan dan persengketaan. Jenis ini merupakan akad yang dibuat untuk menghilangkan perselisihan setelah adanya kerelaan masing-masing pihak. ${ }^{12}$ Adapun takharuj tidak harus terjadi setelah adanya persengketaan dan perselisihan namun hanya membutuhkan kesepakatan ahli waris saja.

c. Ishlah kadang-kadang terjadi tanpa adanya ganti atau imbalan (ibra'). Jika dalam ishlah itu menggugurkan hak orang-orang yang berselisih atau sebagian dari hak itu. Terkadang menggugurkan hak salah seorang atau kedua belah pihak dan ishlah itu pada dasarnya bukan hanya terjadi dalam harta saja. Adapun takharuj terjadi dengan adanya ganti atau imbalan karena jika tanpa adanya imbalan atau ganti, maka itu bukanlah takbaruj. ${ }^{13}$

3. Al-Bai'

Lafaz al-bai' secara istilah berarti saling tukar menukar harta yang bernilai, dengan cara kepemilikan dan saling memiliki ${ }^{14}$. Ada dua hal yang membedakan jual beli dengan takharuj:

a. Dalam beberapa kondisi, takharuj bukanlah jual beli, karena hanya berbentuk ishlah dan pembagian di antara ahli waris. Karena ahli waris yang keluar terkadang tidak menjual bagiannya dari harta warisan. Hanya mengambil satu bagian dari tirkah atau dari yang lain, disebabkan ia mengundurkan diri sebagai ahli waris.

b. Pada prinsipnya, dalam jual beli orang yang membeli memberikan harga yang pantas secara syara' dan urf untuk benda yang dibelinya kepada si penjual. Adapun dalam takharuj, terkadang ahli waris yang mengundurkan diri itu melepaskan haknya melebihi atau kurang dari bagian warisan yang mesti ia terima karena dasarnya adalah ishlah dan mewujudkan kemashlahatan ahli waris. ${ }^{15}$

Takharuj adalah salah satu dari akad harta pengganti. Bentuknya tidak keluar dari akad pembagian (aqd al-qismah) atau akad jual (aqd al-bai). Jika terjadi kesepakatan bahwa al-kharij (orang yang keluar) itu mengambil harta waris, akad itu disebut sebagai akad pembagian. Apabila terjadi kesepakatan bahwa dia

${ }^{11}$ Manshur bin Yunus al-Buhutiy, Kasyf al-Qina' 'an Matn al-Iqna', (Beirut: Dar al-'Alam al-Kutub, 1403),J il.8, h. 278

${ }^{12}$ Ali Haidar, Syarb Majallah al-Ahkam al-'Adliyyah, (Beirut: Mansurat Maktabah AlNahdhah,t.th), pasal 1531

${ }^{13}$ Ibid.

${ }^{14}$ Ibnu Qudamah, Al-Mughni, (Kairo: Dar Hajr, 1410), cet ke-1, Juz.6, h. 5

${ }^{15}$ Nashir bin Muhammad bin Masyriy al-Ghamidiy, op.cit., h. 197 
mengambil harta yang bukan harta waris yang diserahkan oleh salah satu ahli waris atau oleh semua ahli waris, akad itu disebut akad jual beli.

Takharuj adalah salah satu dari akad harta pengganti. Bentuknya tidak keluar dari akad pembagian (aqd al-qismah) atau akad jual (aqd al-bai'). Jika terjadi kesepakatan bahwa al-kharij (orang yang keluar) itu mengambil harta waris, akad itu disebut sebagai akad pembagian. Apabila terjadi kesepakatan bahwa dia mengambil harta yang bukan harta waris yang diserahkan oleh salah satu ahli waris atau oleh semua ahli waris, akad itu disebut akad jual beli.

Adapun pengertian takharuj secara terminologi, dikemukakan oleh beberapa ulama fikih, di antaranya:

Menurut al-'Alamah Ali bin Muhammad bin 'Ali al-Jurjani al-Hanafiy, dalam kitab at-Ta'rifaat mengemukakan pengertian takharuj yaitu:

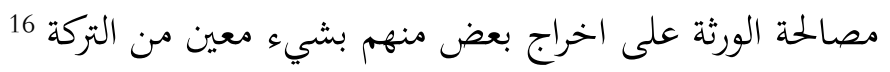

"Kesepakatan abli waris terbadap pengunduran diri sebagian mereka dengan adanya imbalan berapa bagian tertentu dari barta peninggalan".

Menurut Ibn Abidin dalam Hasyiyah Radd al-Mubtar 'ala ad-Durr alMukhtar, makna takharuj yaitu:

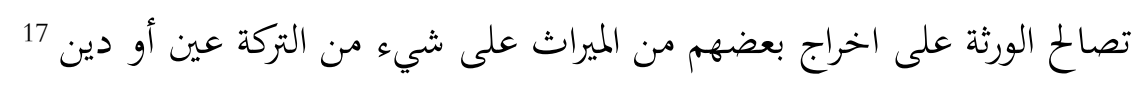

"Perdamaian yang dilakukan abli waris atas pengunduran diri sebagian abli waris yang lain dari menerima harta warisan dengan imbalan tertentu yang diambil dari tirkah baik berupa benda atau butang".

Pengertian yang dikemukakan oleh kedua ulama di atas memiliki arti bahwa takharuj merupakan sebentuk perdamaian yang dilakukan di kalangan ahli waris. Dengan adanya di antara ahli waris yang mengundurkan diri dari menerima warisan. Artinya, ada di antara ahli waris yang mengundurkan diri dalam penerimaan harta warisan, dengan tidak mengambil bagian atau hak warisnya dan tindakan ini disetujui dan disepakati oleh ahli waris lain dengan cara damai. Sebagai kompensasi dari tindakan tersebut, ahli waris yang mengundurkan diri mendapatkan imbalan tertentu yang diambil dari harta peninggalan baik berupa benda atau hutang. H), h. 75

16 Ali bin Muhammad Al-Jurjani, At-Ta'rifaat, (Beirut: Dar al-Kitab al-'Arabiy, 1413

${ }^{17}$ Ibn Abidin, Hasyiyah Radd al-Mubtar 'ala ad-Durr al-Mukhtar, (Beirut: Dar al-Kutub alIlmiyah,t.th), Juz.6, cet ke-2, h. 811 
Pengertian takharuj yang senada dengan pengertian di atas dikemukakan dalam Hasyiyah Qurrah 'Uyun al-Akbbar Takmilah Radd al-Mubtar 'ala ad-Durr alMukbtar Syarb Tanwir al-Abshar, yaitu:

$$
\text { أن يصطلح الورثة على اخراج بعضهم من الميراث بمال معلوم18 }
$$

"Perdamaian yang dilakukan oleh abli waris atas pengunduran diri sebahagian abli waris dari menerima harta warisan dengan adanya imbalan berupa harta tertentu".

Pada dasarnya kedua pengertian takharuj yang dikemukakan di atas memiliki makna yang sama, hanya saja dalam ungkapan yang terdapat dalam Takmilah Radd al-Mubtar lebih sederhana tanpa memerinci bentuk imbalan yang diberikan kepada ahli waris yang mengundurkan diri, apakah diambilkan dari harta peninggalan atau di luar harta peninggalan. Sementara dalam definisi pertama secara tegas dijelaskan bahwa imbalan yang diterima oleh ahli waris sebagai imbalan itu berasal dari harta peninggalan yang ada.

Pengertian takharuj lain diungkakan oleh Abu Zahrah ${ }^{19}$ dalam kitabnya "Ahkam al-Mawarist" dan sepertinya pengertian yang dikemukakan oleh Abu Zahrah lebih terurai dan rinci, bahwa takharuj adalah:

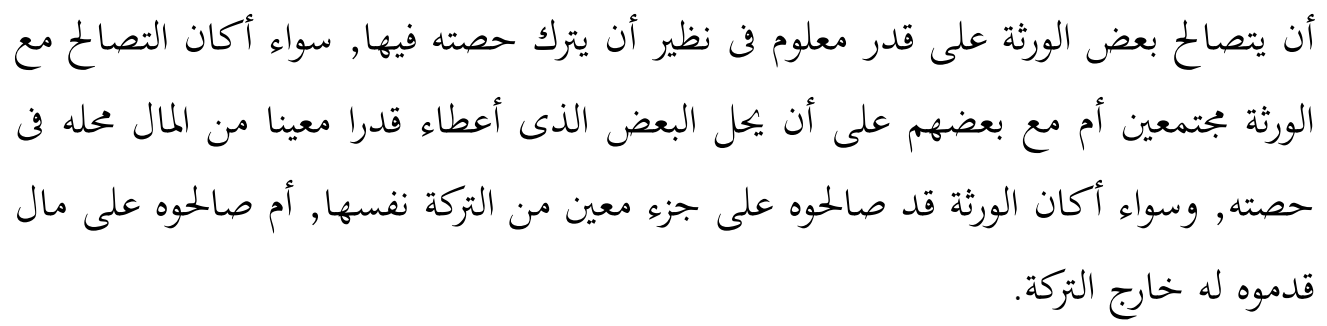

"Perdamaian yang dilakukan oleh abli waris (atas pengunduran diri sebagian mereka dari menerima harta warisan) dengan adanya imbalan tertentu yang seimbang dengan bagiannya dalam harta warisan, baik perdamaian itu dilakukan dengan seluruh abli waris atau sebagian abli waris, bahwa sebagian abli waris melepaskan baknya dengan memberikan bagian tertentu dari harta yang menjadi bagiannya dalam warisan, atau baik apakah abli

${ }_{18}$ Muhammad 'Alauddin Aqriy, Hasyiyah Qurrah Uyum al-Akbbar Talmilah Radd alMubtar 'ala ad-Durr al-Mukbtar Syarh Tanwir al-Abshar, (Beirut: Dar al-Kutub al-Ilmiyah, 1994),Cet.ke-1, Juz.12,h. 348. Syamsuddin Ahmad bin Qaudar, Nataij al-Ifkar (Takmilah Fath alQadir oleh Ibn Humam) Syarb Bidayah al-Mubtadiy, (Li al-Thiba'ah an-Nasyr wa al-Tauzi': Dar alFikr, t.th), Juz.8, h. 439

19 Muhammad Abu Zahrah, Abkam at-Tirkah wa al-Mawarits, (Kairo: Dar al-Fikr al'Arabiy, 1963), h. 218 
10 | Al-Istinbath: Jurnal Hukum Islam, Vol. 3, No. 1, 2018

waris melakukan perdamaian (dengan abli waris yang mengundurkan diri) atas bagian tertentu itu diambil dari harta warisan atau dari selain harta warisan".

Dari definisi takharuj yang dikemukakan di atas ada beberapa poin penting dalam praktek takharuj, yaitu:

1. Adanya perdamaian atau kesepakatan (pengunduran diri) yang dilakukan oleh ahli waris dengan ahli waris lain, baik perdamaian itu dilakukan dengan seluruh ahli waris atau sebagian ahli waris. Dalam arti kata, takharuj dapat saja dilakukan oleh seorang ahli waris dengan seluruh ahli waris atau seorang ahli waris dengan salah seorang ahli waris atau lebih.

2. Bentuk perdamaian tersebut dengan cara sebagian ahli waris melepaskan hak waris yang menjadi bagian warisannya dengan adanya imbalan yang diberikan dan diambil dari harta warisan atau selain dari harta warisan.

Berdasarkan pengertian takharuj di atas, kata takharuj mengalami penyempitan makna ketika dilihat pengertiannya secara lughah dan istilah. Dalam pengertian lughah menampung persoalan apa saja yang dilakukan melalui perdamaian dan pengunduran diri. Namun dari pengertian secara terminologi atau istilah, takharuj yang dimaksud hanya berlaku dalam hal perdamaian dan pengunduran diri dalam penerimaan harta warisan saja.

Adanya beberapa pengertian terminologi yang dikemukakan oleh beberapa ulama fikih di atas dapat disimpulkan bahwa takharuj merupakan penyesuaian yang berlaku dalam pembagian warisan. Adanya kesepakatan ahli waris untuk menempuh cara pembagian warisan di luar cara yang ditentuakan oleh syara'. Cara pembagian yang dimaksud adalah perdamaian yang terjadi di kalangan ahli waris dengan adanya salah seorang atau beberapa orang ahli waris yang mengundurkan diri (melepaskan haknya) dari menerima harta warisan, dengan imbalan tertentu yang bisa saja diambil dari harta warisan atau dari harta ahli waris sendiri. Harta benda yang seharusnya ia terima, dibagikan kepada ahli waris selainnya sesuai dengan bagiannya masing-masing. Dengan demikian dia tidak mengambil bagian yang setara dengan haknya dari harta waris atau dari hal lainnya. Ini dapat dikatakan bahwa dia menghapus bagian warisnya sendiri. itu adalah:

Dengan demikian dapat dijelaskan bahwa di antara karakteristik takharuj

1. Takharuj merupakan suatu perdamaian atau kesepakatan (perjanjian) yang diadakan oleh ahli waris atau para ahli waris untuk mengundurkan (mengeluarkan) salah seorang ahli waris dalam menerima warisan dengan memberikan suatu tebusan atau pengganti yang diberikan oleh orang yang mengundurkan kepada yang mengundurkan diri. 
2. Tebusan atau pengganti tersebut dapat berasal dari harta ahli waris atau dari harta peninggalan yang akan dibagi-bagikan.

3. Takbaruj dilakukan sebelum harta warisan dibagikan dan diperuntukkan kepada masing-masing ahli waris atau sebelum ahli waris mengetahui bagian warisan masing-masing.

Dalam beberapa buku dan tulisan ulama mazhab Hanafiyah, penulis tidak menemukan pengertian takharuj secara istilah yang dikemukakan oleh sebagian ulama mazhab ini, seperti dalam kitab Badai' al-Shanai', Babr ar-Raiq Syarb Kanz ad-Daqaiq dan lainnya, sehingga untuk melengkapi uraian pengertian takharuj ini penulis mencantumkan beberapa pengertian takharuj yang diungkapkan oleh ulama lain seperti Mubammad Abu Zabrab dan Ali Haidar sebagaimana yang telah dijelaskan sebelumnya.

Menurut Merwan al-Qadumi dalam tulisannya yang berjudul "al-Shulhu bi at-Thariqiy al-Takharuj fi al-Mirast, dalam Qanun Mesir yang membahas tentang kewarisan persolan takharuj dibahas pasal 48, dalam Qanun al-Abwal alSyakhshiyyah Suria terdapat pada pasal 303. Bunyi teksnya adalah "Takharuj merupakan kesepakatan atau perdamaian antara ahli waris atas keluarnya sebagian mereka dari menerima warisan dengan adanya imbalan tertentu". Dalam Qanun al-Madani Urdu, ketentuan tentang takharuj terdapat pada pasal 539 sampai 542, yang mengandung hukum jual beli, akan tetapi terhadap objek jual beli yang sudah ditentukan ketika akad itu dan dibatasi di antara ahli waris. ${ }^{20}$

\section{Bentuk-bentuk Takharuj}

Dalam pelaksanaannya, penyesuaian secara takharuj dapat berlaku dalam tiga bentuk. Bentuk pertama, persepakatan di antara dua orang ahli waris untuk keluarnya salah seorang di antaranya dari pembagian warisan dengan imbalan tertentu yang dibarikan oleh pihak lain dari hartanya sendiri. ${ }^{21}$ Dalam bentuk pertama ini berarti bahwa orang yang keluar itu menyerahkan hak warisan yang akan diterimanya kepada salah seorang ahli waris lain. Hak itu oleh yang menerimanya digantinya dengan hartanya sendiri. Pada waktu pembagian warisan, di samping menerima haknya sendiri ia juga menerima hak ahli waris yang keluar. Pada hakikatnya, cara ini adalah jual beli hak warisan karena tidak menyangkut kepentingan dan hak ahli waris yang lain, maka persepakatan ini cukup berlaku di antara dua pihak saja tanpa melibatkan ahli waris yang lain.

Bentuk kedua, persepakatan seluruh ahli waris atas keluarya salah seorang dari kelompok waris, dengan imbalan yang dipikul bersama dari harta

${ }^{20}$ Merwan al-Qadumi, al-Shulh bi al-Thariq al-Takharuj fi al-Mirast, (Palestina: Jami'ah anNajah al-Wathaniyah, 2009), h.311

${ }^{21}$ Yusuf Musa, at-Tirkatu wa al-Mirasu fi al-Islam, (Kairo:Dar al-Ma'rifah, 1960), h. 375 
mereka di luar hak yang akan mereka terima dari harta warisan. ${ }^{22}$ Pada hakikatnya bentuk kedua ini sama dengan bentuk pertama yaitu ahli waris yang keluar menjual haknya kepada ahli waris yang lain. Bedanya ialah bahwa yang membeli di sini adalah seluruh ahli waris. Dalam pembagiannya sama dengan yang pertama yaitu semua ahli waris ditetapkan haknya sesuai dengan ketentuan yang berlaku. Kemudian hak dari yang keluar diberikan kepada ahli waris yang lain. Tentang cara penentuan bagian ahli waris yang keluar untuk ahi waris yang tinggal, tergantung kepada kesepakatan mereka pada waktu membeli hak ahli waris yang keluar.

Bentuk ketiga ialah kesepakatan semua ahli waris atas keluarnya salah seorang di antaranya dari kelompok penerima warisan dengan imbalan tertentu dari harta peninggalan itu sendiri. ${ }^{23} \mathrm{Hal}$ ini berarti salah seorang memilih untuk mengambil bentuk tertentu dari harta warisan sedangkan yang lain diserahkannya untuk ahli waris yang tinggal, untuk selanjutnya pembagian berlaku di antara ahli waris yang tinggal itu.

Bila diperhatikan bentuk ketiga ini terlihat bahwa masalahnya berbeda dengan dua bentuk yang di atas karena pada bentuk ketiga ini menyangkut dengan cara pembagian. Artinya ahli waris menempuh cara pembagian yang menurut lahirnya menyimpang dari cara yang ditentukan oleh hukum faraid. Dengan diberikannya hak pilih kepada ahli waris untuk menentukan bagiannya yang ada kemungkinan lebih kurang dari hak yang semestinya diterimanya, menyalahi prinsip ijbari.

\section{Dasar Pelaksanaan Takharuj}

Dasar yang dipakai oleh ulama yang membenarkan lembaga takharuj itu ialah kerelaan dan kesepakatan pihak yang berhak menerimanya. Para ahli waris adalah orang yang berhak menerima harta tersebut, hingga dapat pula bertindak atas haknya itu sesuai dengan kemauan dan kerelaannya.Di samping itu ulama tersebut juga mendasarkan kepada asar sahabi dari Abu Yusuf dari Amru ibn Din ar yang berasal dari Ibn Abbas bahwa salah seoang janda Abdurrahman ibn 'Auf bernama Tumadir mengadakan persetujuan dengan tiga orang dari jandanya yang lain untuk keluar dari kelompok penerima warisan suaminya dengan imbalan yang diterinanya sebanyak 83 dirham. $^{24}$

Asar sahabi tersebut tidak cukup kuat untuk dijadikan dalil untuk menyimpang dari ketentuan umum yang berlaku. Tetapi ternyata di kalangan ulama Hanafiyah yang biasa berfikir praktis menggunakannya atas dasar kerelaan

\footnotetext{
22 Ibid., h. 375

${ }^{23}$ Abu Zahrah, Abkam at-Tirkah wal Mirast, (Kairo: Dar al-Fikr al-Arabiy, 1962), h.267

${ }^{24}$ Yusuf Musa, op.cit., h. 375
} 
dan penerimaan bersama dari pihak yang berhak. Cara ini juga diikuti oleh Hukum Kewarisan yang berlaku pada waktu ini di Mesir. ${ }^{25}$

Jika dikaitkan dengan pembagian warisan secara takharuj yang membolehkan ahli waris menerima bagian kurang atau melebihi dari bagian yang seharusnya ia terima, dalam salah satu bentuk takharuj tentunya akan bertentangan dengan prinsip ijbari dan ayat yang mengatur pembagian waris. Di samping itu, dalam takharuj sebelum dilaksanakan pembagian harta warisan, ahli waris dapat melakukan persekapatan dalam bentuk ishlah, dengan adanya kerelaan dari ahli waris yang lain. Ishlah yang dimaksud dengan memberikan imbalan sebagai ganti terhadap bagian ahli waris yang mengundurkan diri. Sementara dalam prinsip hukum kewarisan Islam, tidak membenarkan pembagian harta warisan sebelum ahli waris mengetahui hak waris masingmasing.

Pembagian harta warisan dalam bentuk takharuj memang tidak dijumpai dasar hukumnya baik dalam al-Qur'an maupun hadis Nabi saw. Dasar hukumnya merupakan hasil ijtihad (atsar sahabat) atas peristiwa yang terjadi pada masa pemerintahan Khalifah Usman bin Affan. Ada beberapa redaksi atsar tersebut yang ditemui dalam beberapa kitab hadis, di antaranya adalah sebagai berikut:

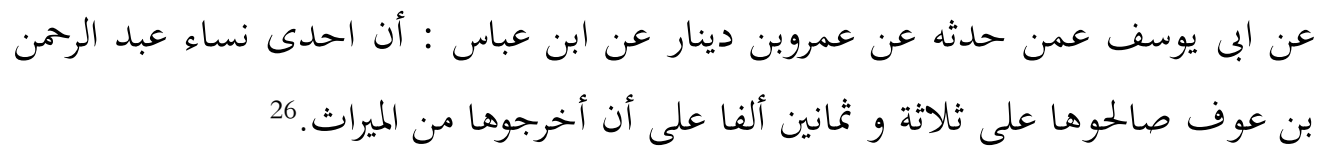

'Dari Abi Yusuf dari seseorang yang menceritakan kepadanya, dari Amru bin Dinar dari ibnu Abbas: Salah seorang istri Abdurrahman bin 'Auf diajak untuk berdamai oleh para abli waris terhadap harta sejumlah delapan pulub tiga ribu dengan mengeluarkannya dari pembagian harta warisan".

Redaksi lain atsar tersebut berbunyi:

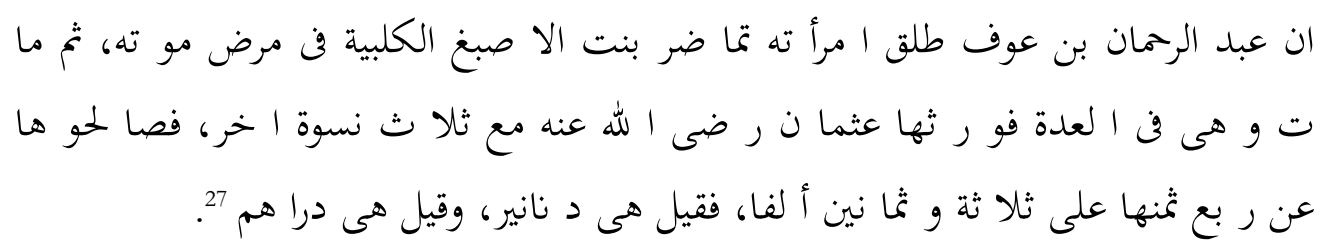

${ }^{25}$ Abu Zahrah, Ahwal-al-Syakhshiyyah, (Kairo: Dar al-Fikr al-'Arabiy,1973), h.270

${ }^{26}$ Beberapa redaksi atsar sahabat ini diambil kitab Muhammad Nashir al-Din Albaniy, Irwaa' al-Ghalil Fi Takhrij Ahaadis Manar, (Beirut: Maktab al-Islamiy, 1985), Cet. Ke-2, Juz. 2, hadis ke 98. 
"Abdurrabman bin 'Auf, di saat sekaratnya, mentalak isterinya yang bernama Tumadhir binti al-Ishbagh al-Kalbiyah. Setelah ia meninggal dunia dan isterinya sedang dalam masa iddah, sayyidina Utsman r.a. membagikan pusaka kepadanya beserta tiga orang isterinya yang lain. Kemudian mereka pada mengadakan perdamaian dengannya, yakni sepertigapuluh dua-nya, dengan pembayaran delapan puluh tiga ribu, dikatakan oleh suatu riwayat "dinar" dan dikatakan oleh riwayat yang lain "dirbam"

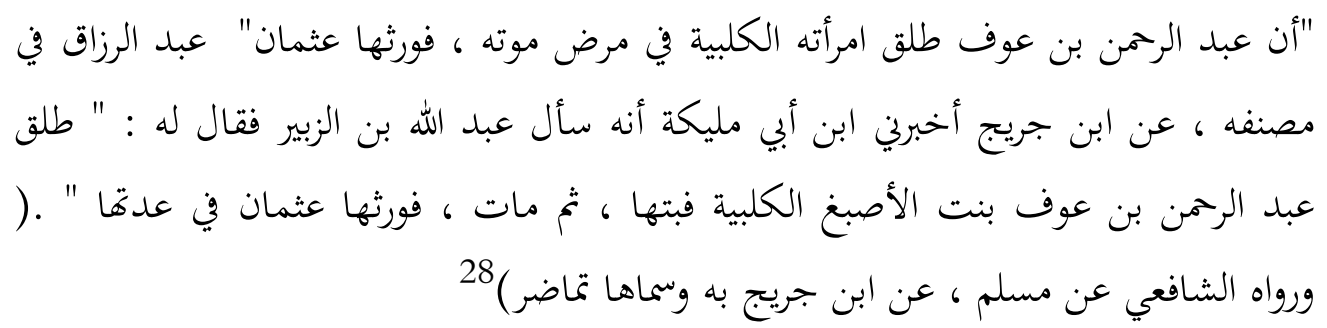

"Bahwa Abdurrabman bin 'Auf mentalak isterinya Kalbiyah pada saat maradh maut, kemudian Usman tetap memberikan bak waris kepada (isterinya tersebut). Abdurrazzaq dalam kitabnya mengatakan bahwa atsar ini berasal dari Ibn Juraij dari Ibn Abi Malikah bahwa ia pernah bertanya kepada Abdullah bin Zubair dan Abdullab berkata kepadanya: Abdurrabman bin 'Auf telah mentalak anak perempuan Ashbagh yang bernama alKalbiyah, kemudian setelah itu ia meninggal dan Usman tetap memberikan bak waris kepada isteri (Abdurrabman bin 'Auf tersebut) dalam masa iddabnya. (HR. Al-Syafi'i dari Muslim, dari Ibn Juraij, ia menamakan perempuan itu dengan Tumadir).

Hadis ini merupakan hadis muttashil. Ibn Zubair mengomentari hadis ini bahwa menurutnya ia tidak melihat Tumadir itu mewarisi harta Abdurrahman bin 'Auf disebabkan telah ditalak tiga. Riwayat lain ditemukan dalm kitab alMuwaththa Imam Malik yang berasal dari Ibn Syihab dari Talhah bin Abdullah bin 'Auf dari Abi Salamah bin Abdurrahman bahwa Abdurrahman bin 'Auf telah menceraikan isteriny. Ia sedang dalam keadaan sakit, lalu Usman memberikan hak waris isteri Abdurrahman bin 'Auf itu setelah habis masa iddahnya. Menurut al-Syafi'i, hadis ini termasuk hadis munqathi' sedangkan hadis Ibn Zubair di atas adalah hadis muttashil. Adapun menurut Ibn Sa'ad dalam kitab Thabaqat, hadis yang diriwayatakan bahwa Usman memberikan hak waris kepada Tumadhir binti al-Ashbagh dari harta warisan Abdurrahman bin 'Auf dan ia ditalak pada waktu sakit menjelang ajal, merupakan hadis shahih."

27 As-Sayyid as-Syarif, Syarh as-Sirajiijah, h. 237; Yusuf Musa, at-Tirkah wa al-Mirats, op.cit., h. 375. Muhammad Nashir al-Din Albaniy, op.cit.,Juz. 8, h. 219

${ }^{28}$ Nashir al-Din Albaniy, op.cit., hadis ke- 1393

${ }^{29}$ Ibid. Lihat juga Al-Sarakhsi, Furu' al-Figh al-Hanafiy, (Beirut: Dar al-Ma'rifah, 1989), h. 
Menurut riwayat Muhammad bin Mash'ab al-Qarqasani dari al-Auza'iy dan az-Zuhri dari Thalhah dari Abdullah, bahwa Usman bin Affan memberikan hak waris kepada Tumadhir binti al-Asbagh al-Kalbiyah dari (harta) Abdurrahman dan Abdurrahman mentalaknya pada saat sakit menjelang kematiannya dengan talak satu, bukan dalam bentuk talak tiga. ${ }^{30}$

Terdapat riwayat lain dari Ibn Syihab dari Thalhah bin Abdullah bin 'Auf berkata, inilah yang mereka amalkan. Dari Abi Salamah bin Abdurrahman bin 'Auf " bahwa Abdurrhman bin 'Auf mentalak isterinya dengan talak tiga pada saat sakit menjelang kemtiannya, namun Usman tetap memberikan hak waris kepada isteri Abdurrahman tersebut setelah habis masa iddahnya". Menurut Ibn Syihab ini merupakan sanad yang shahih berdasarkan syarat alBukhari. Sementara al-Baihaqiy meriwayatkan dari thuruq Ibn Syihab juga dengan redaksi: 'Saya pernah mendengar Muawiyah bin Abdullah bin Ja'far bericara kepada al-Walid bin Abdul Malik -Kami ketika itu berada antara Makkah dan Madinah -dan ia berkata : Ya Amiral Mukminin...Ini adalah as-Saib bin Yazid, anak laki-laki saudara perempuan Tumadhir yang menyaksikan bahwa Usman memberikan hak waris kepada Tumadhir binti Asbagh dari harta yang ditinggalkan Abdurrhaman bin 'Auf r.a setelah ia bercerai dan ia menyaksikan Usman memberikan kepada Ummu Hakim binti Qarith hak waris yang ditinggalkan Abdullah bin Makhal setelah ia bercerai. Panggillah ia dan tanyakanlah tentang kesaksiannya". Menurut al-Baihaqiy ini merupakan sanad yang muttashil. Namun menurut saya, Muawiyah bin Abdullah tidak termasyhur dan tidak ada yang menilai ia tsiqqah selain Ibn Hibban dan al-'Ajliy. Menurut al-Hafizh dalam kitab al-Taqrib riwayat ini termasuk riwayat yang diterima (maqbul). ${ }^{31}$

Dari atsar sahabat tersebut, dipahami bahwa pembagian harta waris dengan menggunakan perinsip musyawarah dan damai dilakukan oleh para janda dan anak Abdurrahman bin 'Auf dengan cara salah seorang jandanya menyatakan keluar dari haknya untuk menerima harta warisan suaminya, namun dengan imbalan pembayaran uang sejumlah delapan puluh tiga ribu dinar dan ada yang menyatakan delapan puluh tiga ribu dirham. ${ }^{32}$

Istri (janda) almarhum Abd. Rahman bin 'Auf berjumlah 4 orang, dan salah seorang di antaranya bernama Thumadhir binti al-Ashbag menyatakan mengundurkan diri dari bagian yang seharusnya diterima dengan imbalan

${ }^{30}$ Ibid.,

${ }^{31}$ Ibid.,

32 Al-Marginani, al-Hidayah Syarb Bidayah al-Mutadiy, (Beirut: Dar al-Nasyr al-Maktabah al-Islamiyah,t.th), Juz.3 h, 200, Jawindiy, Syarh al-Sarajiyyah li Syarif al-Jurjani ,(Turki: ttt,tth), h. 236, Ibn Humam, Fath al-Qadir, h. 4408, Syarah Muwaththa' Malik, Jil 4, h. 109 
pembayaran sejumlah uang. Bagian Thumadhir adalah $1 / 4$ dari $1 / 8$ atau $1 / 32$ dari keseluruhan harta warisan pewaris. Bagian tersebut dinilai dengan uang sejumlah 83 dirham atau ada yang menyatakan 83 dinar. ${ }^{33}$

Menurut Ibn Abbas, takharuj yang dilakukan oleh ahli waris dengan adanya sebagian yang mengundurkan diri atau keluar dari menerima warisan dengan cara ishlah adalah sesuatu yang dibolehkan. Menurut Ibn Abbas, cara ini merupakan salah satu cara memudahkan dalam pembagian warisan karena dengan adanya ahli waris yang keluar maka ahli waris yang tinggal tidak akan kesulitan lagi untuk membagi harta warisan. Alasan yang dimunculkan Ibn Abbas ini menurut penulis tidak memiliki dasar yang kuat karena hanya berpegang kepada logika semata. ${ }^{34}$

Selain atsar sabahat, dasar hukum al-takharruj adalah analogi terhadap setiap terjadi muamalah jual beli dan tukar menukar atas dasar kerelaan masingmasing, sehingga sepanjang terjadi kerelaan dan kesepakatan, perjanjian pembagian harta warisan dengan metode takharruj menurut ulama Hanafiyah hukumnya boleh. Jadi, takharuj adalah pembagian harta warisan secara damai dengan prinsip musyawarah. Pembagian harta warisan dengan metode tersebut, para ahli warislah yang berperan dan berpengaruh dalam menentukan, baik cara pembagiannya maupun besar bagian para ahli waris. Pembagian harta warisan dalam bentuk ini dapat saja keluar dari ketentuan pembagian harta warisan yang telah ditetapkan berdasarkan al-Qur'an dan hadis Rasulullah SAW., namun atas dasar kesepakatan dan kerelaan antara para ahli waris untuk kemaslahatan para ahli waris. Para ahli waris mempunyai peranan dan pengaruh dalam menentukan cara pembagian dan besarnya bagian dari masing-masing mereka. Sekalipun pembagian tersebut membuat beberapa prinsip dalam hukum kewarisan Islam diabaikan.

\section{Pandangan Ulama Hanafiyah Terhadap Praktek Takharuj}

Hanafiyah dan jumhur ulama berbeda pendapat dalam hal dalil yang digunakan dalam membolehkan takharuj. Ini terkait dengan kedudukan dalil tersebut dalam metode istinbat hukum mereka. Perbedaan ini menjadi penyebab perbedaan mereka dalam nenetapkan hukum takharuj.

Hukum kewarisan ditetapkan dengan dalil yang qathi'i, yaitu al-Qur'an dan Sunnah. Di dalamnya telah dijelaskan secara terperinci tentang bagaimana cara membaginya, siapa yang berhak menjadi ahli waris dan berapa bagian masing-masing. Di samping itu al-Qur'an dan Sunnah juga menegaskan tentang

\footnotetext{
${ }^{33}$ Yusuf Musa, op.cit., h. 375

${ }^{34}$ Ibid.,
} 
keharusan untuk membagi harta warisan tersebut sesuai dengan apa yang telah ditetapkan. Sementara kalangan Hanafiyah di samping mengikuti ketentuan yang telah ditetapkan dalam al-Qur'an dan Sunnah tersebut, memiliki pandangan yang berbeda dalam hal memahaminya. Ketika terjadi peristiwa takbaruj seperti yang ada dalam atsar tersebut, Hanafiyah dengan rasional membolehkannya. Dengan cermat Hanafiyah menempatkan takharuj sebagai salah satu bentuk jual beli harta warisan sehingga dianggap tidak bertentangan dengan prinsip kewarisan Islam. Perbedaan Hanafiyah dengan jumhur terletak pada bagaimana kedudukan atsar tersebut dalam dalil yang mereka gunakan ketika mengistinbatkan hukum. Penulis menilai bahwa atsar yang dimaksud tersebut dalam dalil yang digunakan oleh Hanafiyah adalah qaul shahabi atau fatwa sahabat..$^{35}$ Dalil ini termasuk ke dalam dalil yang tidak disepakati oleh para mujtahid. (Ijmak al-shahabah as-sukuti)

Qaul Sbahabi atau seiring disebut dengan Fatwa Shahabi dan Mazhab Shahabi adalah perkataaan atau pendapat seorang sahabat tentang sebuah perkara. Hal ini banyak dilakukan oleh para sahabat tentang sebuah perkara dan banyak dilakukan oleh para sahabat setelah wafatnya Nabi SAW seiring dengan banyaknya pertanyaan atau perkara yang diajukan pada mereka. Qaul shababi berbeda dengan ijma' al-shahabi dari segi kakuatan dan sumbernya. Qaul shababi merupakan pendapat sahabat secara perorangan dan kedudukannya masih diperselisihkan oleh para ahli ushul. Bahkan menurut Amir Syarifuddin, ${ }^{36}$ Asnawi dalam kitabnya Syarb Minhaj al-Ushul menempatkan qaul shababi sebagai dalil syar'i yang ditolak. Sedangkan ijma' al-shababi adalah dalil syara' yang mempunyai kedudukan yang kuat dan tinggi karena diterima oleh semua ahli ushul.

Hanafiyah sendiri dalam penggunaan dalil menempatkan qaul shababi pada posisi yang tinggi di bawah al-Qur'an dan Sunnah. Hanafiyah tidak mempermasalahkan apakah qaul shahabi tersebut berasal dari beberapa orang sahabat atau hanya dari satu orang saja, karena dalam hal ini Hanafiyah menilai bahwa sahabat adalah orang yang banyak bergaul bersama Rasulullah. Mereka pun turut menyaksikan proses turunnya wahyu dan bagaimana hukum dibentuk.

${ }^{35}$ Qaul shababi merupakan pendapat para sahabat Rasulullah SAW tentang suatu kasus yang dinukil para ulama, baik merupakan fatwa maupun kettapan hukum, sedangkan ayat atau hadis tidak menjelaskan hukum terhadap kasus yang dihadapi sahabat tersebut. Di samping belum adanya ijma'para sahabat yang menetapkan hukum tersebut. Muhammad Abu Zahrah, Ushul al-Fiqh, (Mesir: Dar al-Fikr al'Arabi, 1998), 309.

36 Amir Syarifuddin, Ushul al-Figh, (Jakarta: Logos Wacana Ilmu, 2001), Cet.ke-2, h. 378 
Karena itu pengetahuan mereka dekat dengan kebenaran sehingga Hanafiyah dapat menerima qaul shahabi meskipun hanya berasal dari satu orang. ${ }^{37}$

Penulis menilai bahwa dalil takharuj memang lemah karena hanya berupa atsar dan tidak ada dalil pendukung lainnya. Atsar itupun hanya menceritakan satu kali peristiwa takharuj yang terjadi dan tidak ada peristiwa selainnya. Namun demikian dalil tersebut dapat menjadi kuat dengan memasukkan unsur-unsur pendukung lainnya. Misalnya dengan mengaitkan fungsi atsar sebagai bayan (penjelas) dari nash-nash al-Qur'an dan Hadist. Kemudian dalil dapat juga dikuatkan dengan melihat mashlahah yang diperoleh dari peristiwa takharuj tersebut.

Ulama Hanafiyah menyebutkan bahwa takharuj dibolehkan karena ia adalah sebagai bentuk jual beli harta warisan (dalam prakteknya memang terjadi semacam transaksi jual beli, yaitu ahli waris yang keluar menerima imbalan dari ahli waris yang lain sebagai ganti atas harta warisan yang menjadi haknya). Hal pokok yang mendasari pendapat Hanafiyah ini adalah adanya imbalan yang diberikan kepada ahli waris yang keluar. Pemberian imbalan itulah yang mengisyaratkan telah terjadi transaksi jual beli di antara kedua belah pihak penjual dan di sisi lain ahli waris yang menerima adalah sebagai pihak pembeli. Sedangkan yang menjadi objek jual belinya adalah bagian atau furud yang belum jelas. Dalam prakteknya keridhaan dari ahli waris yang menerima menjadi tolok ukur.

Penulis melihat bahwa Hanafiyah menjadikan atsar tersebut sebagai dalil mereka untuk membolehkan takharuj dengan beberapa alasan, diantarana peristiwa takharuj tersebut terjadi pada masa khalifah Usman bin 'Affan. Ketika peristiwa tersebut terjadi, ia memperbolehkan dan tidak melarangnya. Persetujuan Usman ini dianggap sebagai fatwa. Hanafiyah dalam metode istinbat hukumnya menempatkan fatwa sahabat sebagai salah satu dalil hukum di bawah al-Qur'an dan Sunnah. Dengan posisi tersebut maka fatwa itu dijadikan dalil yang kuat oleh Hanafiyah dalam membolehkan takharuj.

\section{Resistensi (Penolakan) Jumhur Ulama Terhadap Takharuj}

Penolakan jumhur ulama terhdap konsep takbaruj dapat dilihat dari beberapa sisi. Pertama, jumhur ulama hanya menerima qaul shababi yang dikeluarkan secara kolektif sebagai dalil yang kuat. Qaul shahabi yang dikeluarkan oleh satu orang sahabat saja rentan dengan kesalahan. Ini menunjukkan bahwa

37 Al-Bannani, Hasyiyah al-Bannani 'ala Syarh al-Mahalli 'ala Matn JamiI al-Jawami', (Beirut: Dar al-Kutub al-'Ilmiyyah, 1983, h. 288, Saifuddin al-Amidi, al-Ihkeam fi Ushul al-Abkam, (Beirut: Dar al-Kutub al-Ilmiyyah, 1983), Jilid III, h. 133 
jumhur ulama sangat hati-hati dalam menerima sesuatu sebagai dalil karena akan berdampak pada produk hukum yang dihasilkannya.

Pendapat Hanafiyah yang menyebutkan bahwa takharuj dibolehkan karena ia adalah sebagai bentuk jual beli harta warisan (dalam prakteknya memang terjadi semacam transaksi jual beli, yaitu ahli waris yang keluar menerima imbalan dari ahli waris yang lain sebagai ganti atas harta warisan yang menjadi haknya) merupakan pandangan yang tidak rasional dan tidak tepat mengingat bahwa secara substansi takbarij tidak seperti akad jual beli pada umumnya. Hal pokok yang mendasari pendapat Hanafiyah ini adalah adanya imbalan yang diberikan kepada ahli waris yang keluar. Pemberian imbalan itulah yang mengisyaratkan telah terjadi transaksi jual beli di antara kedua belah pihak penjual dan di sisi lain ahli waris yang menerima adalah sebagai pihak pembeli. Sedangkan yang menjadi objek jual belinya adalah bagian atau furud yang belum jelas.

Dalam konteks jual beli secara umum, ada rukun-rukun yang harus dipenuhi agar jual belinya dianggap sah. Rukun-rukun tersebut adalah penjual, pembeli, barang yang diperjualbelikan, dan ijab kabul. Namun hal ini berbeda dengan rukun jual beli versi Hanafiyah. Menurut mereka, rukun jual beli adalah ijab kabul yang menunjukkan keridhaan dari penjual dan pembeli untuk melakukan transaksi. Penulis melihat bahwa Hanafiyah memandang keabsahan jual beli pada substansi pelaksanaanya. Keridaan antara penjual dan pembeli sudah mencakup segalanya yang terkandung dalam proses transaksi. Melihat kepada proses takharuj secara jelas memang tidak terlihat adanya transaksi jual beli seperti jual beli pada umumnya karena hanya dikategorikan sebagai jual beli dengan adanya perpindahan kepemillikan disertai dengan keridhaan dari masingmasing pihak.

Terlihat dari paparan di atas, ulama Hanafiyah dengan cermat menempatkan takharuj sebagai salah satu bentuk jual beli warisan sehingga membuatnya tidak bertentangan dengan prinsip kewarisan Islam. Pada prinsipnya takharuj merupkan salah satu cara pembagian harta warisan dengan menggunakan prinsip-prinsip musyawarah. Para ahli waris mempunyai peranan dan pengaruh dalam menentukan cara pembagian dan besarnya bagian dari hak yang akan diterima masing-masing ahli waris. Namun pembagian tersebut membuat beberapa prinsip dalam hukum kewarisan Islam diabaikan. Inilah yang menjadi dasar bagi mayoritas ulama untuk menolak praktek takharuj yang dikembangkan oleh ulama Hanafiyah. Di antara prinsip dalam hukum kewarisan Islam yang diabaikan itu adalah Menyalahi Prinsip Ijbari Dalam Hukum Kewarisan Islam. 
Apabila dilihat cara pembagian secara takharuj, peralihan harta itu berlaku atas kehendak dari ahli waris yang dilakukan melalui kesepakatan bersama atau musyawarah, bukan beralih dengan sendirinya. Selain itu, dalam salah satu bentuk pembagian warisan secara takbaruj, bagian warisan yang diterima oleh masing-msiang ahli warispun tidak sesuai dengan ketentuan yang ada dalam nash, bisa saja lebih dari bagian yang seharusnya diterima ahli waris atau kurang yang hanya didasarkan kepada kerelaan ahli waris semata. Hal ini menyalahi prinsip ijbari dari segi peralihan harta dan bagian yang mesti diterima ahli waris.Dalam takharuj, lebih banyak diserahkan kepada keinginan masingmasing ahli waris karena takharuj itu dilakukan sebelum pewaris meninggal, ketika hak waris itu belum jelas. Padahal secara prinsip selama pewaris itu belum meninggal maka hak-hak kewarisan itu belum jelas, mungkin harta itu berkurang dan mungkin juga bertambah. Dari segi ini, takharuj juga berbenturan dengan prinsip ijbari sebagai salah satu asas dalam hukum kewarisan Islam.

Dalam pembagian warisan secara takharuj, pembagian harta warisan dilakukan sebelum adanya kematian dari yang memiliki harta. Tidak adanya peristiwa kematian dari yang memiliki harta menyebabkan tidak terjadinya peralihan harta dalam kewarisan, sehingga belum bisa dikatakan bahwa harta warisan itu telah menjadi hak milik ahli waris. Hal ini pun berarti ahli waris tidak memiliki hak dan wewenang apapun terhadap harta tersebut, selama yang memiliki harta belum meninggal.

Melihat kepada proses takharuj secara jelas memang tidak terlihat adanya transaksi jual beli seperti jual beli pada umumnya karena hanya dikategorikan sebagai jual beli dengan adanya perpindahan kepemillikan disertai dengan keridhaan dari masing-masing pihak. Sementara objek yang diperjualbelikan belum jelas.

Kemashlahatan yang dituju dalam takharuj adalah memenuhi kebutuhan ahli waris namun untuk mencapai kemashlahatan tersebut berbenturan dengan nash yang qath'i, prinsip dalam hukum kewarisan Islam dan prinsip muamalah.

\section{Penutup}

Sebagai hasil temuan dalam penelitan ini dapat disimpulkan bahwa, Takbaruj merupakan perdamaian yang terjadi di kalangan ahli waris dengan adanya salah seorang atau beberapa orang ahli waris yang mengundurkan diri (melepaskan haknya) dari menerima harta warisan, dengan imbalan tertentu yang bisa saja di ambil dari harta warisan atau dari harta ahli waris sendiri. Ulama Hanafiyah menggunakan takharuj sebagai solusi hukum atau billah syar'i dengan didasarkan kepada keridhaan ahli waris yang akan menerima warisan. Sekalipun harta itu dibagi sebelum pewaris meninggal dan dapat berlaku dalam bentuk jual 
beli warisan (dapat saja terjadi hak yang diterima tidak sesuai dengan hak yang semestinya), selama ahli waris yang ada setuju maka hal itu dapat diterima. Praktek takharuj pun pernah dilakukan oleh sahabat dengan dasar atsar sahabat.

Adapun penolakan jumhur ulama terhadap konsep takharuj yang dikemukakan oleh ulama Hanafiyah disebabkan beberapa hal, di antaranya: Pertama, menyalahi prinsip ijbari dalam kewarisan dari segi peralihan harta dan bagian ahli waris. Kedua, takharuj dilakukan sebelum pembagian harta warisan atau sebelum pewaris meninggal. Ketiga, takharuj dianggap sebagai jual beli warisan namun objek yang diperjualbelikan belum ada atau belum jelas. Keempat, tujuan dilakukan takharuj untuk kemashlahatan ahli waris namun dalam mencapai tujuan tersebut menyalahi dan berbenturan dengan dalil qath'i, prinsip dalam kewarisan dan prinsip muamalah.

Berdasarkan hasil temuan di atas penulis menilai bahwa dasar hukum yang menjadi pegangan ulama Hanafiyah untuk melakukan takharuj dipandang lemah karena hanya didasarkan kepada atsar sahabat. Selain itu, banyak titik lemah yang ditemui dalam praktek takharuj karena berpotensi menyalahi nash yang qath'i, beberapa prinsip dalam kewarisan Islam dan prinsip dalam muamalah.

\section{Daftar Pustaka}

Ahmad bin Qaudar,Syamsuddin, Nataij al-Ifkar (Takmilah Fath al-Qadir oleh Ibn Humam) Syarh Bidayah al-Mubtadiy, Li al-Thiba'ah an-Nasyr wa alTauzi': Dar al-Fikr, t.th, Juz.8

Al-Amidi, Saifuddin al-Ihkam fi Ushul al-Ahkam, Beirut: Dar al-Kutub alIlmiyyah, 1983, Jilid III.

Aqriy, Muhammad 'Alauddin, Hasyiyah Qurrah 'Uyuun al-Akhbar Talmilah Radd al-Muhtar 'ala ad-Durr al-Mukhtar Syarh Tanwir al-Abshar, Beirut: Dar al-Kutub al-Ilmiyah, 1994,Cet.ke-1, Juz.12

Al-Bannani, Hasyiyah al-Bannani 'ala Syarh al-Mahalli 'ala Matn JamiI alJawami', Beirut: Dar al-Kutub al-'Ilmiyyah, 1983.

Al-Baniy, Muhammad Nashir al-Din Irwaa' al-Ghalil Fi Takhrij Ahaadis Manar, Beirut: Maktab al-Islamiy, 1985, Cet. Ke-2, Juz. 2

Al-Buhutiy, Manshur bin Yunus, Kasyf al-Qina' 'an Matn al-Iqna', Beirut: Dar al-'Alam al-Kutub, 1403, Jil.8 
C.S.T Kansil, Pengantar Ilmu Hukum dan Pengantar Tata Hukum Indnesia, Jakarta: Balai Pustaka, 1976.

Dirdjosisworo, Soedjono Penganatar Ilmu Hukum, Jakarta: CV.Rajawali, 1984, cet.Ke-1

Al-Ghamidiy, Nashir bin Muhammad bin Masyriy at-Takhaaruj Baina alWaratsah Ahkamuhu wa Shuwaruhu fi al-Fiqh al-Islamiy, Makkah alMukarramah: Jami’ah Ummul Quro,.t.th.

Haidar, Ali, Durar al-Hukkam Syarh Majallah al-Ahkam, Beirut: Maktabah AnNahdhah, t.th, juz. 3.

Ibn Abidin, Hasyiyah Radd al-Muhtar 'ala ad-Durr al-Mukhtar, Beirut: Dar alKutub al-Ilmiyah,t.th,Juz.6,cet ke-2.

Ibn Humam, Fath al-Qadir, h. 4408, Syarah Muwaththa' Malik, Jil 4.

Ibn Manzur, Lisan al-Arab, Beirut : Dar Shadir, t.th, Jilid 4.

Ibnu Qudamah, Al-Mughni, Kairo: Dar Hajr, 1410, cet ke-1, Juz.6t., h. 197

Jawindiy, Syarh al-Sarajiyyah li Syarif al-Jurjani ,Turki: ttt, t.th.

Al-Jurjani, Ali bin Muhammad At-Ta’rifaat, Beirut: Dar al-Kitab al-‘Arabiy, 1413 $\mathrm{H}$

Al-Marginani, al-Hidayah Syarh Bidayah al-Mutadiy, Beirut: Dar al-Nasyr alMaktabah al-Islamiyah,t.th, Juz.3.

Mausu'ah Fiqhiyyah Al-Kuwaitiyah, Kuwait: Zaratul Auqaf wa as-Syu'un alIslamiyah, 1408), cet ke-2

Musa, Yusuf at-Tirkatu wa al-Mirasu fi al-Islam, Kairo:Dar al-Ma'rifah, 1960.

Al-Sarakhsi, Furu' al-Fiqh al-Hanafiy, Beirut: Dar al-Ma'rifah, 1989.

Soekanto, Soerjono dan Sri Mamudji, Penelitian Hukum Normatif : Suatu Tinjauan Singkat, Jakarta: PT. Rajagrafindo Persada, 1983.

Syarifuddin, Amir, Hukum Kewarisan Islam, Jakarta: Prenada Media, 2004. -, Ushul-Fiqh, Jakarta: Logos Wacana Ilmu, 2001, Cet.ke-2.

Al-Syathibi, Abu Ishaq al-Muwafaqat fi al-Ushul I, Kairo: t.tp, t.t.

Zahrah, Muhammad Abu, Ahkam at-Tirkah wal Mirast, Kairo: Dar al-Fikr alArabiy, 1962.

, Ahwal-al-Syakhshiyyah, Kairo: Dar al-Fikr al-'Arabiy,1973

, Ushul al-Fiqh, Mesir: Dar al-Fikr al'Arabi, 1998. 